Fear and the failure of security 
Arianto Sangaji - 9789004260436

Downloaded from Brill,come4/26/2023 09:42:14AM via free access 


\section{ARIANTO SANGAJI \\ The security forces and regional violence in Poso}

\section{Introduction}

The term 'security forces' in this chapter refers to the Indonesian national military (Tentara Nasional Indonesia, TNI), the Indonesian national police (Kepolisian Republik Indonesia, Polri), and intelligence institutions such as the national intelligence agency (Badan Intelijen Negara, BIN) - in short, the three institutions that carry out the security and order functions in Indonesia. ${ }^{1}$ By 'regional violence', I mean violence that is limited to a particular region within the archipelago. It may take the form of vertical violence, as in Aceh, where we find conflict between the state and people fighting for independence, or of horizontal violence, such as the violence with ethnic and religious dimensions in Ambon and Poso. Ideally, the security forces should carry out their duties in a way that does not conflict with democratic norms and is subject to the authority of the civilian government. The use of TNI forces should be limited to facing threats from external enemies and providing support to the legitimate institution for handling domestic emergencies. It is the police who have the authority to maintain domestic order, while the state intelligence service secretly gathers information to assist the other security forces. Actions by the security forces within these bounds are legitimate and satisfy citizens' expectations of safety. However, quite apart from the various, complex, and possibly mutually contradictory hidden motives of the security forces during Indonesia's current political transition, I intend to demonstrate that the security forces actually reap benefits from the regional violence in Poso by engaging in a series of actions outside the limits of their legitimate functions.

1 I would like to express my special thanks to Gerry van Klinken for his useful criticism and input on this paper. 


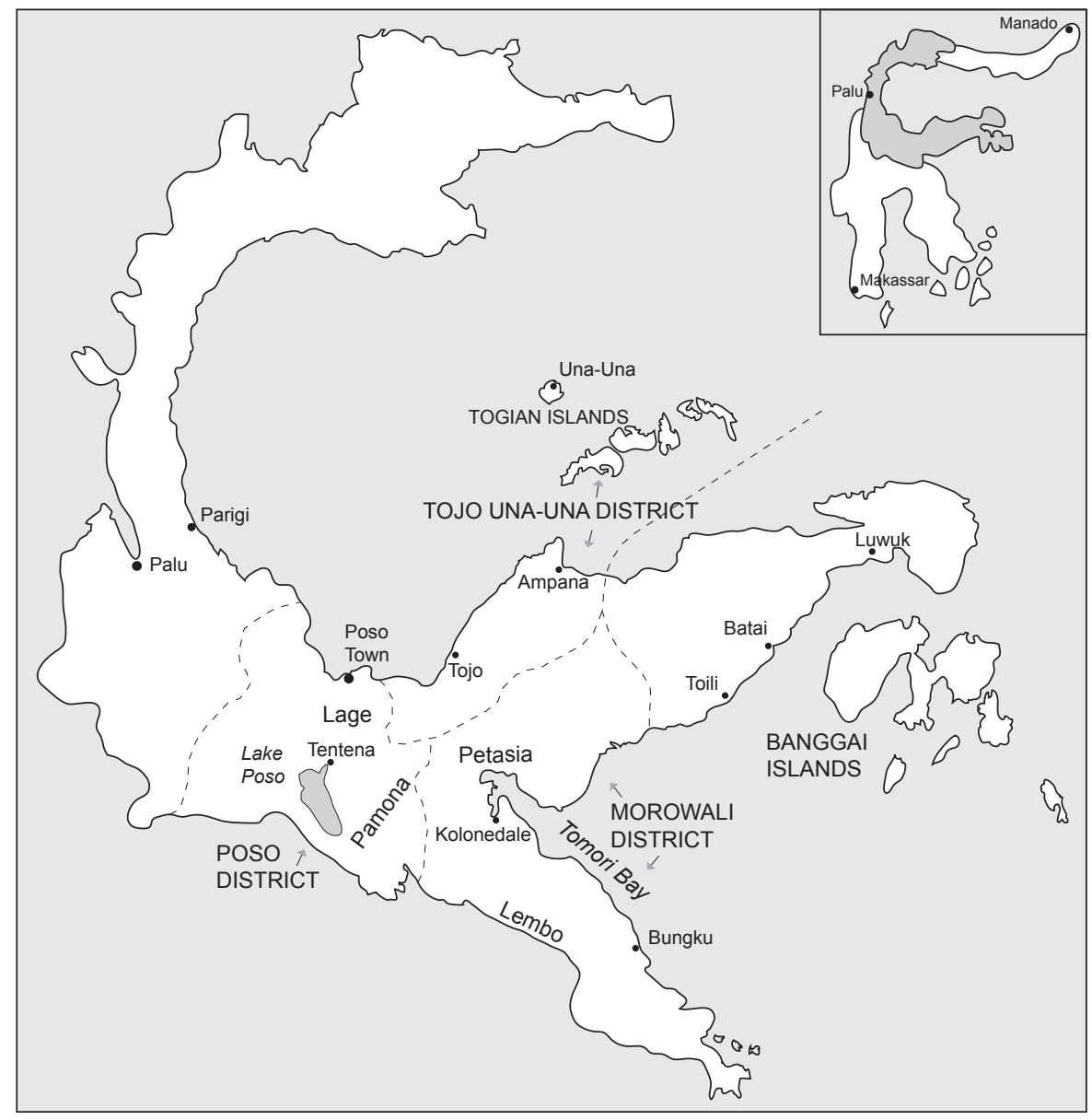

Map 10. Central Sulawesi (2) 
The security forces and regional violence

Links between the security forces (in particular the army, Tentara Nasional Indonesia-Angkatan Darat, TNI-AD) and regional violence have been a staple of Indonesian politics since the 1950s. In the cases of the Pemerintah Revolusioner Republik Indonesia (PRRI, the Revolutionary Government of the Indonesian Republic) and Permesta rebellions, the strife was related to internal conflicts within the TNI itself and to the dissatisfaction of TNI commanders in the regions with the central government (Leirissa 1991). The response to this regional violence then provided an entry for the TNI to participate in managing governmental and economic affairs once the state of military emergency was declared in March 1957 (Sundhaussen 1988; Crouch 1978). Using this foothold, and especially after the 30 September 1965 incident, the security forces consolidated their presence in the political and economic spheres, as well as in their legitimate domain of security.

The Reformasi of 1998 was a turning point. The security forces could no longer enjoy the many political privileges they had held during the New Order era. This change was signalled by the elimination of the positions of chief of social and political staff (Kasospol) and chief of territorial staff (Kaster), the elimination of the military's dual function (dwifungsi), the liquidation of kekaryaan (posting of military personnel to civilian positions) and the social-political function, and the removal of the TNI/Polri factions from legislative institutions by 2009 (Departemen Pertahanan RI 2003:14). The Coordinating Board for Consolidation of National Stability (Bakorstanas) and the Special Investigation Institution (Litsus) were also liquidated through Presidential Decree no. 38/2000. As a consequence, the military's control over political life declined sharply.

Yet Reformasi did not dismantle all the military's privileges. Two important aspects remained untouched. First, despite criticisms, military business activities continued, both 'institutional' and 'non-institutional' businesses, $^{2}$ and economic crimes (Singh 2001; McCulloch 2000:28-32). The military has been involved in economic activity since the early 1950s, primarily to earn extra-budgetary income. This activity has included collection of illegal taxes from the business community and more organized activity, such as

2 Institutionally, there are three forms of military involvement in business: First, cooperatives aimed at the welfare of their members and their families; second, business units managed by foundations for the purpose of welfare and education; and third, miltary involvement in stateowned companies, such as Pertamina, Bulog, and Berdikari (Indria Samego 1998:67-8).

The definition of non-institutional military businesses is businesses conducted by retired military personnel, by family of military personnel, or by military personnel themselves outside official channels (for example the other foundations or business entities affiliated with armed forces or the police) (Indria Samego 1998:97). 
smuggling. This involvement increased significantly in 1958-1959, when the military acquired control over Dutch companies that were nationalized (Robison 1986:250-1).

Second, the TNI's Territorial Commands (Komando teritorial, Koter), which have existed since the 1950s, were maintained (Sundhaussen 1988:24850). Even after Reformasi, the Koter, which played a very important role during the New Order era, comprising the Military Area Commands (Komando daerah militer, Kodam), Military Sub-Area Commands (Komando resort militer, Korem), Military District Commands (Komando distrik militer, Kodim), Military Precinct Commands (Komando rayon militer, Koramil), and Village Management NCOs (Bintara pembina desa, Babinsa), were all retained. In the past, these Koter had been the military's main political instrument to rein in citizens' political activity. This situation means that the military still has a strong footing from which to control the life of the citizenry.

The regional violence since the Reformasi of 1998 has, in any case, actually improved the security forces' bargaining position vis-à-vis the civilian government. In response to regional violence, the military has mobilized large numbers of troops from year to year. This implies that the civilian elite has failed to impose civilian supremacy over the military or to provide nonmilitary solutions to solve regional problems (Kammen and Chandra 2003). At the regional level, local governments will again turn to the TNI to find an element that can stabilize the unpredictable political climate, and the military will continue to enjoy access to economic resources in the regions and to maintain its organizational autonomy (Mietzner 2003:256-7).

With reference to regional violence, at the national level the TNI has taken the initiative to force its interests on the civilian government. The proposed Bill on TNI, which was full of 'political' articles, was evidence of TNI's unwillingness to abandon practical politics. The inclusion of a clause on placement of actively-serving TNI personnel in departmental and nondepartmental structures is evidence of this. ${ }^{3}$ One article in the draft Bill first proposed by TNI headquarters granted the TNI commander the authority to take military action without the president's consent (Tempo 16-3-2003). In the end, however, Law no. 34/2004 put the authority and responsibility for mobilizing TNI forces in the hands of the president.

It is generally agreed that the regional violence in Poso has taken place in several episodes since December 1998. The public uses the term Poso I for the incidents that occurred in December 1998, Poso II for April 2000, and Poso III for May-June 2000; Poso IV broke out in early July 2001, and Poso V with the attacks on several villages in sub-district (kecamatan) Poso Pesisir in late November 2001 (Ecip, Darwis Waru and Alip Yog Kunandar 2002:8-40). Since

See Article 47 of Law no. 34/2004 on the Indonesian National Military (TNI). 
the Malino Meeting in December 2001, sporadic violence has continued in the form of mysterious attacks.

\section{Perpetuation of conflict}

I believe that the security forces, both institutionally and as individuals, have sustained the conflict in Poso. This perpetuation of the conflict can be observed in several aspects: toleration of violence, engaging in violence outside the limits of their duties, distribution of firearms and ammunition, mysterious shootings/killings, rivalry between armed units, mobilization of troops, and relations between the security forces and laskar (partisan militias).

\section{Toleration of violence}

The term 'toleration of violence' refers to situations in which the security authorities do not take the necessary legitimate and professional preventive and repressive action to end conflict. It takes the form of simply allowing open physical contact between disputing parties, or of mobilizing troops to the location of the violence but too late to properly intervene.

The humanitarian tragedy in Poso indicates how deep this toleration has been. In the case of the mass slaughter of Muslim residents in Sintuwu Lemba Village (Lage sub-district) in May 2000, the Crisis Centre of the Central Sulawesi Christian Church (CC GKST) produced a report on the chronology of the case. ${ }^{4}$ The report stated that members of the security forces allowed the battle between the two sides to take place. When armed conflict broke out between residents in Sintuwu Lemba Village on 28 May 2000, the security forces who were at the location actually left the scene. However, three sources from among residents who survived the Sintuwu Lemba incident confirm that not all the security forces left the scene of the incidents; some of them were directly involved in the fighting.

If they had wanted to prevent the violence at Sintuwu Lemba, the security forces could easily have done so. The headquarters of Company B, Infantry Battalion 711 (Kompi B Yonif 711/Raksatama) in Kawua is only around 7 kilometres, or five minutes, from the scene of the incident. And the Lage police sector (polsek) station in Tagolu Village is only around 1 kilometre from Sintuwu Lemba. Yet it is known that a number of village residents were tortured and killed near the Tagolu village administration building.

The actions of soldiers in the field seem to have reflected the attitudes 
of their commanders. The commander of Korem 132 Tadulako, Colonel Hamdan Z. Nasution, behaved very strangely when an attorney, Karman Karim, brought one of the Sintuwu Lemba victims to meet him. When the victim, Ilham, told of the torture he had experienced, the commander lightly replied, 'Why didn't you resist?' And when Ilham said that a soldier from Company 711 Raksatama just sat and watched the torture of the Sintuwu Lemba residents, Hamdan simply listened cynically (Mingguan Alchairaat 91, June 2000).

Toleration of violence also occurred when armed conflict broke out between Muslim and Christian groups at Bridge II between Kawua and Ronononcu Villages in Poso Kota on 12 November 2001. The armed conflict began at around 7.15 a.m., but the security forces only arrived at the location at around 12.15 p.m. Yet much earlier, at 8.05 a.m., Pastor Damanik from CC GKST had contacted Lt. Col. (Inf.) Syamsurizal Harahap, commander of Kodim 1307 Poso, to stop the violence. This is very strange, since it is only around 5 kilometres from the Kodim 1307 Poso headquarters to the scene, and around 1 kilometre from the headquarters of Yonif 711/Raksatama (Damanik 2003:71-2).

\section{Engaging directly in conflict}

Security forces are known to have been directly involved in violence in Poso outside their legitimate duties. During Poso III (May-June 2000), in which hundreds died, many army and police personnel are suspected of direct involvement. No fewer than 29 army and police personnel were interrogated by the military police. Of seven individuals identified as being seriously involved, two were army officers with the rank of captain (Surya 7-7-2000; Formasi 48, July 2000). Then, following investigations, two NCOs and one enlisted man from Kodim 1307 Poso were declared suspects by the Military Police Detachment (Detasemen Polisi Militer, Denpom) VII/2 Palu. ${ }^{5}$

Earlier, the commander of Korem 132/Tadulako, Infantry Colonel Hamdan $Z$ Nasution, stated that the involvement of the military and police personnel was limited to supplying instant noodles and rice (Detik.com 23-6-2000). But this statement was only intended to avert a greater responsibility following the emergence of various accusations of involvement by military personnel. In their testimony to the Palu Military Police Detachment, the three army personnel, with the initials $\mathrm{MR}, \mathrm{CP}$ and $\mathrm{AT}$, admitted supplying ten rounds of ammunition to one of the parties to the conflict in Poso. Furthermore, during the TNI's month-long Operation Love of Peace (Operasi Cinta Damai), the 
security forces seized thousands of bullets from civilians (Detik.com 7-7-2000). Many of these civilians stated that they had received the ammunition from military and police personnel.

Involvement of police personnel is also acknowledged. During the humanitarian tragedy of Poso III, the Central Sulawesi regional police chief (Kepala kepolisian daerah, Kapolda) reported that he planned to take four of his personnel to court, as they were suspected of involvement in the unrest. Two of them, with the initials HP and SS, were members of the Poso police Subregion. They assisted a certain group when it carried out attacks in several places in Poso Pesisir sub-district (Pedoman Rakyat 21-7-2000).

From reports of official sources - both Muslim and Christian - it is very clear how deeply army and police personnel were involved. For example, the official publication of Laskar Jihad - one of the Muslim militia groups fighting in Poso - Buletin Laskar Jihad (Edition 15, year I) reported that individuals from Army Company B, Infantry Battalion 711/Raksatama in Kawua, Poso abducted and shot dead seven residents of Toyado village. One of the corpses was thrown off a military truck in Ronononcu Village, Lage, clearly to make it appear that the murder had been committed by a Christian group.

Perhaps because they were so blatantly involved in the violence, these TNI personnel were caught by the legal system. The National Human Rights Commission (Komnas HAM) considered their acts to be human rights violations (Kompas Cyber Media 11-12-2001). From these cases, the commander of Denpom VII/-2 Palu, MP Lt. Col. Wempi Hapan, later stated that 14 personnel from TNI Company B Infantry Battalion 711/Raksatama had been designated as suspects. Two of them were officers (second lieutenants) and the remainder enlisted men. They were charged with abduction, shooting, murder, and torture and were to be tried in Military Court 17, Manado, North Sulawesi (Radar Sulteng 16-7-2003; Sinar Harapan 17-7-2003).

On the other side, reports from CC GKST stated that personnel from Brimob - the Mobile Police Brigade, or special combat forces - engaged in shooting on 27 July 2001 that killed three Christian residents. Later, the secretary of CC GKST stated that 17 Brimob personnel attacked Batugencu Village on the evening of 12 August 2002. Following the attack, residents found many cartridge cases from organic weapons (Suara Pembaruan 14-82002; $M A L$, week II, August 2002). Five persons were killed and 500 houses burned in the attack.

Direct involvement in violence also occurred in the 12 November 2001 incident at Jembatan II, Poso. During armed contact between Muslim and Christian groups, three men in TNI uniforms suddenly appeared on a hilltop and let loose a volley of shots directed at the Muslim forces. Around 15 minutes later, the three came down the hill and left the location by motorcycle, heading toward Lage. Pastor Damanik from CC GKST, who had come to help 
evacuate residents, witnessed this incident (Damanik 2003:72).

Violence committed by the security forces has taken other forms as well. For example, Brimob Private First Class Zakeus (Jack) Juan (who was drunk at the time) shot at a 'Honda Jaya' intercity bus heading toward Luwuk, capital of district (kabupaten) Banggai (6 February 2003), killing a passenger from Toili, the main transmigration area in Banggai district (Radar Sulteng 8-2-2003, 30-4-2004).

\section{Distribution of firearms and ammunition}

One reason the violence in Poso has been so protracted is the security authorities' loss of control over the spread of small arms. The security forces are completely unable to stem the traffic in firearms and ammunition, whether from illegal sales and barter, smuggling in from abroad, or support from certain parties within the country. In fact, the security authorities are themselves often connected with the traffic in firearms and ammunition.

For the general public, the only satisfactory answer to explain the spread of organic weapons and ammunition into the hands of civilians must be a connection with the official security institutions, since they hold the exclusive right to control the distribution of arms and ammunition throughout the nation. Furthermore, it is the duty of the security forces to investigate the sources for the spread of organic arms and ammunition; a properly conducted internal investigation would surely reveal their origin. No concrete steps have yet been taken to trace the ultimate sources for the spread of arms and ammunition. Consider, for example, the seizure of 2,846 rounds of ammunition sent to Poso on the Pelni passenger ship KM Ngapulu, which arrived from Java at the port of Pantoloan, Palu on 3 October 2002. The plastic ammunition box was labelled PT Pindad (Kompas 5-10-2002; Nuansa Pos 510-2002; Jakarta Post 9-10-2002). In this case, the police only arrested the field operators, Farihin Ibnu Ahmad alias Yasir and Anto (Nuansa Pos 5-10-2002). The police should have further investigated how the ammunition changed hands from PT Pindad to Farihin and his associates.

Much earlier, in the attack on Sepe Village (Lage subdistrict), on the evening of Sunday, 1 December 2001, a case of $5.56 \mathrm{~mm}$ calibre bullets was found. The box, with the PT Pindad logo and a capacity of 1,400 bullets, was labelled 'Poso' in marker and ' $\mathrm{B}$ ' with paint. It can therefore be surmised that this 25-kilogram case of bullets was allocated to Company B, Infantry Battalion 711 Raksatama in Kawua, Poso, but 'somehow' found its way into the hands of the insurgents in the village. According to the data on the munitions case, the ammunition was made by PT Pindad in March 1989 under contract no. KJB/004/DN/M/1988 dated 12 March 1988 (Aditjondro 2004b:42). 
There have been many such cases of distribution of these illicit materials in Poso. In a police operation in mid May 2004 in Poso Kota, Poso Pesisir, Lage, Pamona Utara, and Pamona Selatan sub-districts, the security forces found three crates of $5.56 \mathrm{~mm}$ calibre ammunition produced by PT Pindad. They also found 11 homemade rifles, one revolver, 200 rounds of $5.56 \mathrm{~mm}, 12.7$ $\mathrm{mm}$, and $7.76 \mathrm{~mm}$ calibre ammunition, walkie-talkies, ski masks, knapsacks, and a bullet-proof vest reading 'Kopassus' (Komando Pasukan Khusus, the Army Special Forces) (Detik.com 14-5-2004).

The spread of firearms and ammunition in Poso (and also in Palu) is like an iceberg. The successful sweeps by the security forces uncover only the topmost layer, while below the surface, there is far more that remains unseen. Many residents possess firearms and ammunition, store them in PVC pipes, and hide them underground. Several informants are certain that many business operators in Poso possess illegal firearms.

So where did all these guns come from? It is undeniable that the laskar (partisan fighters) who came to Poso brought in some of them. Two separate laskar primary sources confirm that they brought various types of firearms into Poso starting in 2000, including revolvers, AK-47s, M16s and SKS. ${ }^{6}$ Furthermore, Agus Dwikarna - leader of Laskar Jundullah - said that he obtained four AK-47s from Ambon to be used in Central Sulawesi. Agus revealed this at Darul Jalal mosque on 24 December 2001 and was monitored by BIN (Conboy 2004:228, 231). Another primary source who admitted taking part in the attack on the Brimob headquarters in Tantui, Ambon said that a number of SKS, revolvers, and US army carbines - perhaps he meant US M1 Carbines - were taken to Poso. ${ }^{7}$ It is well known that this attack led to the loss of hundreds of organic weapons belonging to the police.

But it is also possible that members of the security forces, both active and retired, sell weapons to civilians. One source in Poso confessed that in March 2001 he had been offered M-16s for Rp 7 million apiece (around US\$ 700 at that time), SS-1s for Rp 5 million and FN-45s for Rp 2.5 million. If he agreed, the broker would put him in touch with a source in the security forces.

The most blatant abuse has to do with the traffic in ammunition. Many residents admit that they have obtained various types of ammunition directly from the security forces. A $5.56 \mathrm{~mm}$ calibre bullet can be bought from an individual in the security forces for between $\operatorname{Rp} 3,000$ and $\operatorname{Rp} 5,000$. Typically, whenever 'BKO' troops (Bawah Kendali Operasi, Under Operational Control; for example troops brought in from another region) are withdrawn, residents can obtain bullets easily - through purchase, barter for deer antlers, or even for free. 
Not all the firearms and ammunition in circulation come from the security forces or related institutions. Another important source is smuggling from the nearby southern Philippines. Typically, M-16 weapons are smuggled in using the 'leapfrog' method, that is, from island to island in the Sangihe Talaud island chain of North Sulawesi, and eventually brought to Poso (Radar Sulteng 27-10-2003). Smugglers also bring weapons from the southern Philippines through Tawao (Malaysia) and then to Nunukan (East Kalimantan), and then on to Poso. When the security situation heats up, the weapons are brought into Poso by sea, often at night using fishing boats. In contrast, when the situation is relatively calm and the security forces slacken their checks of vehicles coming in and out of Poso, it becomes easy to smuggle in weapons by car or even motorcycle.

The smuggling routes through Nunukan and Sangihe Talaud are common knowledge. In early 2000, the North Sulawesi sub-district police foiled an attempt to smuggle weapons on the motor vessel KM Daya Sakti, which sails the route between Bitung (North Sulawesi) and General Santos City (Philippines), in the waters off Pulau Buang, Sangihe Talaud (Gamma 28-32000). The Philippines' National Security Advisor, Roilo Golez, has acknowledged that weapons are smuggled from the southern Philippines to Indonesia (Sinar Harapan 28-8-2001). National police Chief General Da'i Bachtiar stated that the southern Philippines was the source of the weapons used by the armed group that attacked in Beteleme in October 2003 (Jakarta Post 3-112003). And Nasir Abbas, an accused Jemaah Islamiyah figure, stated in court in Palu on 4 October 2003 that the Jemaah Islamiyah network had smuggled weapons through the Tawao-Nunukan route. All this indicates that the security forces certainly have sufficient information to fight weapons smuggling.

In any case, without efforts to trace the sources of weapons and ammunition, the security restoration operations that take place in Poso are no more than a joke. If nothing is done to investigate, prevent, and crack down on the sources of the weapons in circulation, violence can erupt at any time. As a result, in these operations, the security forces are simply acting as firemen; they come and put out the fire, leave, and get ready to be called again when the violence resumes.

Admittedly, it is very difficult to stem the flow of home-made weapons. And given the protracted nature of the violence, local residents have become increasingly skilled at producing such weapons. Even though tens of thousands of homemade firearms have been seized from residents, it is very easy for them to produce new ones. Workshops in Poso, Ampana, Parigi, Tentena, Kolonodale, and Palu have stepped up their output as producers of locally-made firearms. Home-made arms started to be produced on a large scale during Poso phase III (May-June 2000), when Poso residents suddenly 
received photocopies containing patterns for guns, both long and short barrel, from an unknown source.

According to the Head of Matako Village, just one day after the attack on the village on 22 July 2001, the commander of the Poso Military Area Command, Lt. Col. Syamsurizal Harahap, came to the village. Speaking to the village head and a number of residents, he advised the residents to arm themselves. The weapons should not be used to attack, but only for selfdefence. Residents immediately responded by buying or making firearms. They then obtained ammunition easily by buying it from the security forces posted in their village.

\section{Mysterious shootings/ killings}

One dominant form of violence since the Malino Declaration in December 2001 has included shootings, bombings, and murders with sharp weapons by unknown persons. This pattern signals a major change from the previous forms of violence, which were characterized by open attacks involving large numbers of people. For the sake of simplicity, we will refer to these mysterious attacks as 'Petrus' (from the Indonesian penembakan misterius, mysterious shootings), a term widely used in Central Sulawesi to describe the events in Poso. However, the term is not limited to shootings by unknown persons and other murders by unknown persons, but refers also to mysterious bombings. The term therefore has a far broader application than the 'Petrus' of the 1980s. ${ }^{8}$

In any case, Petrus has certainly become a frightening spectre for the public, both in Poso and in Palu, the capital of the province of Central Sulawesi. Since 2002, Petrus has claimed many victims (see Table 1). One shocking case occurred on 18 July 2004, when a Petrus attack killed Pastor Susianti Tinulele and injured four of her congregation during services at the Effata Church, Jalan Banteng, Palu municipality.

The Petrus cases always employ more or less the same pattern. The killers use guns (long or short barrelled), knives, or machetes. The perpetrators are small groups of two to four persons. They use motorcycles, usually Yamaha RX King, if the target is in a densely populated or crowded area. In many cases, the shooters/killers wear masks (and are popularly known as 'ninja'), but in other cases they make no effort to hide their faces. Killings have taken place in residents' gardens or fields. Petrus operates both night and day.

The killings are rightly called mysterious, because the security forces

8 At that time, the iron fist of the Suharto government killed between 5,000 and 10,000 alleged members of criminal gangs. Although this Petrus was related to eradication of criminals, it also signalled a conflict within the elite of the security forces (Cribb 2000:191; Bourchier 1990:186).

9 In session on 28 August 2004, the Palu Sub-district Court sentenced 12 of the accused to 
never succeed in shedding any light on the Petrus cases. Typically, the police use their standard answers about the perpetrators: 'The perpetrators have been identified', 'The authorities are conducting a hunt', 'From evidence uncovered at the scene of the crime, the authorities know what type of weapons were used', or 'The authorities have blocked all approaches in and out of Poso/Palu'. Or perhaps, slightly better, they may release sketches of the alleged perpetrators. But aside from this, the security forces do nothing.

Table 1. 'Petrus' cases after the Malino Declaration

\begin{tabular}{lcrrcrrrrrr}
\hline Period & $\begin{array}{l}\text { Shootings } \\
\text { Number } \\
\text { of cases }\end{array}$ & D & I & $\begin{array}{l}\text { Murders } \\
\text { Number } \\
\text { of cases }\end{array}$ & D & I & $\begin{array}{c}\text { Bombings } \\
\text { Number } \\
\text { of cases }\end{array}$ & D & I \\
\hline 2002 & 30 & 21 & 11 & 1 & 1 & - & 17 & 5 & 4 \\
2003 & 11 & 7 & 9 & 3 & 4 & - & 9 & - & 7 \\
2004 & 11 & 7 & 17 & 3 & 3 & - & 5 & 6 & 3 \\
Total & 50 & 35 & 34 & 7 & 8 & - & 31 & 11 & 14 \\
\hline
\end{tabular}

Source: Clippings from local newspapers and Central Sulawesi Regional police D: Dead; I: Injured.

In mid June 2004, in the midst of the election campaign, the police in Ambon arrested four people who were involved in mysterious shooting cases there. One of them had two identity cards (KTP). On his KTP from Palu, he used the name Rizky, while on his KTP from Batumerah, Ambon, he used the name Salman. As well as ID cards and bullets, the police also seized a Lion Air ticket from Makassar to Ambon dated 31 May 2004 and Rp 500,000 in cash. This man, with a crew cut and athletic build, chose to remain silent during the interrogation (Radar Sulteng 15-6-2004). At the very least, this case indicates that the mysterious shooters have high mobility between Poso, Palu and Ambon. Strangely, however, the police did not investigate the possible connections between this person and the several previous mysterious shooting cases in Poso and Palu.

Another form of violence has been attacks by armed groups. Generally, these attacks are done in an organized way, using organic weapons. This was the pattern, for example, in the nearly simultaneous attacks that took place at several different locations in mid October 2003. In Beteleme Village (Lembo sub-district, Morowali district), the attack killed three and injured 20, and the resulting fire destroyed 30 houses, seven motorcycles, and three cars. In this attack, the security forces shot dead some perpetrators and arrested others. ${ }^{9}$

prison terms from two to four years each, while one other was acquitted (Radar Sulteng 30-82004).

10 Interview, 15-9-2004. 
The most dramatic incident occurred in Saatu Village and Pantangolemba Village, (Poso Pesisir sub-district). In this attack, the armed group killed ten persons. In this case, the security forces were unable to discover the identity of the perpetrators, though a person named Iwan was later arrested in Luwuk, on charges of involvement in the attack. All that was recovered from the field following the attack was $205.56 \mathrm{~mm}$ calibre bullets manufactured by PT Pindad (Kompas Cyber Media 12-10-2003).

The mysterious thing about these two cases is the statement by the deputy head of the BIN, As'at Said. He said that the intelligence personnel in the region knew about the possibility of an attack, but the information was late arriving at the centre (Tempo Interaktif 13-10-2003). This statement is not only very strange, but also quite suspicious. How could the security forces know beforehand about an armed attack, yet do nothing about it?

Another interesting point is the strong indications of involvement by the security forces in a number of cases of mysterious shootings in Poso and Palu. The first such incident was the shooting at Bethany Church, Jalan Pulau Kalimantan, Poso on the night of 20 October 2004. This shooting incident, in which Hans Lanipi was shot in the back, was related to the rental of a gun by First Police Brigadier Ray Fendy. A source in the Central Sulawesi regional police stated that Ray had rented his gun for Rp 1.5 million to Andi Makassau, a suspect in a case involving malfeasance in distribution of humanitarian funds for refugees in Poso. The results of ballistic testing showed that Ray's gun was used in this shooting.

Another case involved Deputy Police Commissioner Iskandar Rauf, when there was an attack on the Immanuel GKST Church on Jalan Mesjid Raya, Palu. This shooting and bombing incident on 12 December 2004, which injured Bintijaya, was linked to Iskandar, an officer in the Traffic Directorate of the Central Sulawesi regional police. Central Sulawesi regional police chief Aryanto Sutadi confirmed that the attackers had used a gun that was later identified as belonging to Iskandar. It is not known how the gun fell into the hands of the attackers, because at the time Iskandar was on duty outside Palu.

Thus the sources of the ethnic and religious violence in Poso and Palu are not solely within the community; rather, it is clear that the conflict is also intrinsic to the security forces themselves.

\section{Mobilization of forces}

The mobilization of forces for security restoration operations in Poso is officially under the control of Polri. The involvement of TNI troops is part of their assistance function, generally known in administrative terms as mobilization of forces 'under operational control' of Polri. This is in line with 
the perspective of the national security strategy, in which the Poso violence is categorized as 'low-intensity conflict'. In this situation, TNI involvement is a part of 'military operations other than war' (Department Pertahanan RI 2003:52-3).

The Poso violence was followed by mobilization of large numbers of security troops. Large-scale mobilizations especially began following the violence in May-June 2000. The troops came both from 'organic' (locally based) police and army forces, from the Central Sulawesi regional police and Korem 132/ Tadulako, and from 'non-organic' forces from outside the immediate region. As things developed, the number of troops deployed depended on the level of escalation of the violence.

As usual, the troop mobilizations in Poso used operational code names: Operasi Sadar Maleo, Operasi Cinta Damai, and Operasi Sintuwu Maroso. During the May-June 2000 incident, the Central Sulawesi regional police conducted Operasi Sadar Maleo, while Kodam VII Wirabuana conducted Operasi Cinta Damai, which was under the operational control of the Central Sulawesi police. At that time, the regional police's Operasi Sadar Maleo was led by police Colonel Drs Zainal Abidin Ishak, who was concurrently deputy police chief of the Central Sulawesi regional police. The army's Operasi Cinta Damai Task Force was led by Infantry Colonel Moch. Slamet, who was also territorial assistant of Kodam VII Wirabuana. Later, Zainal Abidin and Moch. Slamet were promoted, respectively, to Central Sulawesi police chief and commander of Korem 132/Tadulako.

After the Malino Declaration in December 2001, the government again deployed a security restoration operation. Code named 'Operasi Sintuwu Maroso', it was to be conducted for a certain period, which could be extended as needed. As things have turned out, Operasi Sintuwu Maroso has now entered Chapter VI; the operation has been repeatedly extended each time new violence breaks out. It seems to have become a regular pattern: each extension of the operation is preceded by a (planned) troop withdrawal. Immediately before or after the withdrawal, new violence occurs - mysterious shootings, killings, bombings, or sporadic attacks. In such cases, the option chosen is to mobilize new troops and/or extend the security restoration operation.

The humanitarian tragedy in Poso has upgraded the status of the army and police presence in Central Sulawesi. Previously, the chief of the Central Sulawesi regional police held the rank of colonel; now it has become brigadier general, because the Central Sulawesi regional police has had its status raised from C to B. In addition, in 2002 the Air Force established a detachment in Palu.

Poso has also become an operational area of Kopassus. Earlier, there were many reports that a number of Kopassus personnel had been posted 
to Tentena and Poso, but this was difficult to confirm. But after a mysterious shooting that killed Lorenzo Taddey, an Italian tourist, near Pendolo (Pamona Selatan sub-district) on 8 August 2002, Wirabuana Military Area Commander Major General Amirul Isnaeni confirmed that Kopassus had sent 12 security personnel to investigate the presence of foreign citizens living in Poso (Jakarta Post 10-8-2002). These personnel had been posted there since mid July 2002 (Kompas Cyber Media 15-9-2002). The Central Sulawesi regional police stated that six Kopassus personnel were posted in Tentena and six others in Poso Kota (Kompas Cyber Media 4-8-2002). But Kopassus was there not only to investigate the presence of foreigners. An official source at the military's Poso National Unity and Public Protection (Kesbang Linmas) Office stated that the 12 Kopassus Special Mission (Sandi Yudha) personnel were in Poso to conduct an intelligence operation.

Later, following a number of incidents of armed conflict in Palu, two Kopassus personnel were placed there as well. Their intelligence operation activities were not limited to gathering information about the violence, but also extended to other issues, such as cases involving land ownership and misappropriation of humanitarian funds intended for Poso.

Thus, the protracted violence in Poso has led to an increased penetration by the security forces into the community. Such opportunities for penetration are in fact now relatively rare in Indonesia, as the country makes its transition to democracy. Suspicions have therefore arisen among the public, which has had such a long experience with militarization of government, that this penetration may itself have given rise to new violence, precisely so that it can become institutionalized.

\section{Rivalry between armed units}

The separation of Polri from the TNI, since 1 April 1999, has led to a type of rivalry between them. The Poso conflict provides an illustration of this. This can be seen from the conflicting statements of the TNI and Polri leaderships in the security restoration operations in Poso. When the Central Sulawesi regional police deployed its Operasi Sadar Maleo starting 1 July 2000, at the same time the Wirabuana Kodam VII began its Operasi Cinta Damai. Strangely, the Central Sulawesi Regional police chief Colonel Drs Soeroso, could not explain the administrative relationship between these two operations. He acknowledged that Operasi Cinta Damai was under the operational control (BKO) of the Central Sulawesi police, but this was done only by telephone. In fact, any such operational control relationship for troops must have a formal administrative basis.

Contradictory statements also appeared in connection with the placement of a Kopassus unit in Poso. The statements by the Wirabuana Military Area 
VII commander and the Central Sulawesi regional police chief were completely opposite. It was known that a dozen Kopassus personnel were posted to Poso, under the direct control of the Wirabuana Military Area commander, and not under the operational control of the Central Sulawesi regional police. The Wirabuana Military Commander, Major General Amirul Isnaeni - a former Kopassus general commander - stated that his organization had coordinated this with the Central Sulawesi regional police.

In contrast, the Central Sulawesi regional police chief Brigadier General Zainal Abidin Ishak, stated that there had been no coordination, but only information (Mingguan Alchairaat, week II, August 2002). Even stranger, the posting of these Kopassus personnel was not acknowledged by their main force. Kopassus's Head of Information, Captain Farid Ma'ruf, denied that any Special Mission (Sandi Yudha) personnel had been sent to Poso. However, the Head of the Army's Information Service, Brigadier General Ratyono, stated that the presence of this intelligence unit was directly responsible to the TNI commander through the assistant for intelligence and the assistant for operations at TNI headquarters (Tempo 25-8-2002).

The commander of Korem 132 Tadulako, Colonel Suwahyuhadji then settled the matter of the Kopassus presence in Poso. He said that at first, these elite troops were brought in without the knowledge of the Central Sulawesi regional police chief, as their arrival was under the direct instructions of TNI headquarters. Later, however, TNI coordinated this with the Central Sulawesi regional police (Kompas Cyber Media 4-8-2002).

Differences of views between the security forces on the violence in Poso are also seen on the issue of involvement of international terrorist networks. The Head of the National Intelligence Agency (BIN), Lieutenant General A.M. Hendropriyono, indicated that the Al Qaeda network was involved in the Poso conflict. In an interview with Buletin Laskar Jihad (Edition 15, year I), Hendropriyono stated that this information came from Spanish intelligence, from their interrogation of captured Al Qaeda members. The captives said that they had trained in Poso (see also Kompas 13-12-2001). But the Central Sulawesi police chief denied this and said that there were no indications of involvement of the Al Qaeda network led by Osama Bin Laden in Poso (Jakarta Post 14-12-2001). The commander of Korem 132/Tadulako, Colonel Suwahyuhadji, also rejected speculation about terrorist training camps in Poso (Kompas 23-10-2003; Jakarta Post 29-10-2002).

\section{Security forces and laskar}

The onset of violence in Poso was followed by the presence of laskar, or armed militias. On the Muslim side, for example, there were Laskar Jihad and Laskar Mujahidin, and on the Christian side, Brigade Manguni. These groups 
employed religious or ethnic sentiments, or a combination of the two. They were relatively well trained in the use of various types of standard combat weapons, in bomb making, and in carrying out attacks on their opponents. The presence of the laskar signalled an important change in the violence in Poso. Up to April 2000, the conflict still used traditional weapons. But with the presence of the various laskar, the nature of the armed violence sharply increased, as signalled by the use of standard combat firearms, home-made firearms, and bombs.

There has long been a relationship between the security forces and laskar or armed groups of civilians in Indonesia. The killings of anywhere between tens of thousands and two million people accused of being Indonesian Communist Party (PKI) members or sympathizers following the 30 September 1965 incident is, of course, the most important example of this (Cribb 1990). The cases of East Timor and Aceh provide other examples of how groups allegedly 'sprang up spontaneously' from within the civilian community, when it was obvious that they were in fact deliberately organized, trained, and supported by the military authorities, with the support of the civilian authorities (G. Robinson 2001). The same pattern occurred with the case of the pam swakarsa (local security forces), in which the military mobilized civilian groups to face the large protest actions being carried out by students following Reformasi in 1998 (Zen 2004:92-8). Central Sulawesi, and especially Poso, has had a similar experience. During the Permesta rebellion in the 1950s (Harvey 1977), youths united in the Central Sulawesi Youth Movement (Gerakan Pemuda Sulawesi Tengah, GPST) worked shoulder to shoulder with the military in eradicating the rebellion. The Indonesian military trained this militia and supplied it with weapons and ammunition.

This pattern of violence has at least two clear aims. First, it provides a shield for the security forces, enabling them to claim that the political violence that occurs is not connected only to them, but also involves civilian groups who happen to share their political views. Second, the security forces can reap political, and of course economic, advantage from situations of instability.

Unlike in the cases of vertical violence such as in East Timor, when the security forces openly support the militias, in cases of horizontal conflict such support is closely concealed. The logic behind this is clear: in vertical conflicts, the security forces can easily mobilize sentiment based on the ideology of the NKRI (Negara Kesatuan Republik Indonesia, Unitary State of the Republic of Indonesia) to justify their actions. In contrast, in cases of horizontal violence, there is no ideological justification for the security forces to support armed militias. This type of concealed support is evident in the case of the Laskar Jihad. Certainly, from the start, the security authorities tolerated the existence of this armed militia group, for example when the Laskar Jihad conducted 
its National Joint Training exercise in Bogor in April 2000. There are even reports that Kopassus personnel provided training to Laskar Jihad members (Kingsbury 2003:208). More fatally, the military failed to take any action against Laskar Jihad when the group decided to go to war in Ambon, even though President Abdurrahman Wahid had openly prohibited this (Prasetyo 2002:180-1; Schulze 2002). This is understandable, as it was widely understood that Lieutenant General Djaja Suparman, Army Strategic Command (Kostrad) commander at the time, had created Muslim militias such as Laskar Jihad, and diplomats in Jakarta said that the disappearance of Rp 160 billion of Kostrad funds - of which Djaja's replacement, Lieutenant General Agus Wirahadikusumah, later made an issue - occurred because the money was used to finance militia operations in Maluku (O'Rourke 2002:371).

The same happened with Laskar Jihad's arrival in Poso. Despite the open announcement of their presence, the security forces did nothing whatsoever to prevent, and even allowed, the arrival of these laskar. Even with over 2,000 TNI and Polri personnel concentrated in Poso at the time, Laskar Jihad was unrestrained when it carried out its attacks. The authorities should have taken stern action to prevent the arrival of Laskar Jihad, in order to prevent an escalation of the violence. On the other hand, the security forces' failure to protect the Muslim community in Poso was also a problem, as this was the excuse for Laskar Jihad's coming to Poso.

The complexity of the relationship between the security forces and militias can also be seen in the case of Brigade Manguni, which is well known for its role in the regional violence in Poso. The connection with Brigade Manguni was revealed by an army deserter named Sonny Mantiri. A secret written intelligence report from the security authorities about armed groups in Poso stated that Sonny led Brigade Manguni, with personnel strength in Poso of around 600 persons, armed with organic weapons. One influential Christian figure in Poso confirmed that Sonny had trained youths from Silanca Village (Lage sub-district) in warfare. ${ }^{10} \mathrm{He}$ was constantly travelling to and from Tentena to obtain ammunition from a source he knew there. Oddly, during the attacks on the Christian community in Sepe and Silanca Villages in August 2002, he 'happened' to be in Tentena. While in Silanca, he had close relations with TNI personnel, but not with the police. When he married a young woman from Silanca in 2001, many TNI personnel attended the wedding party. In mid 2004, he died at Tentena Hospital, with foam coming from his mouth, though the doctors there said he was suffering from hepatitis. Previously, his family had refused to have him treated in Palu, due to rumours that he would be the target of an operation by the security forces.

Brigade Manguni was reported to be close to the security forces. It is 
reported that hundreds of Kopassus personnel who had deserted from their units were ready to train Brigade Manguni. Lieutenant General (retired) Johny Lumintang, former Army Chief of Staff, even supported the establishment of Brigade Manguni. The relationship between Brigade Manguni and the generals is also evident from the Minahasa Adat Congress held on 9 December 2003. It is reported that a number of active and retired officers originally from North Sulawesi supported the conduct of the congress. They included TNI Lieutenant General (retired) E.E. Mangindaan, TNI Lieutenant General (retired) Prabowo Subianto, TNI Lieutenant General (retired) Johny Lumintang, TNI Major General (retired) W.E. Kanter, TNI Major General Glenny Kairupan, and police Brigadier General Wenny Warouw (Radar Sulteng 4-12-2003).

\section{Institutional and personal advantage}

\section{Organic troops and territorial commands}

The violence in Poso has upgraded the presence of organic combat troops in Central Sulawesi, and especially in Poso. This is indicated by the establishment of Infantry Battalion (Yonif) 714/Sintuwu Maroso, with its headquarters on the border between Ronononcu Village (Poso Kota sub-district) and Maliwuko Village (Lage sub-district). Two companies of its troops have been posted: Company B in Malino Village (Petasia sub-district, Morowali district) and Company $\mathrm{C}$ in Pendolo (Pamona Selatan sub-district). It is planned that another company will be posted in Tabalu (Poso Pesisir sub-district). Previously, the province of Central Sulawesi had only one battalion of army combat troops, Infantry Battalion 711/Raksatama, one company of which, Kompi B Yonif 711/Raksatama, is posted in Kawua (Poso Kota sub-district). The commander of Korem 132/Tadulako, Colonel Suwahyuhadji said that the troops were posted for strategic reasons. Because these areas contain natural resource assets, which are vulnerable to disturbances from outside such as looting, and also because of the Poso conflict, these troop postings were more cost effective than bringing in troops from outside (Kompas 5-12-2002).

As if it did not want to be outdone by the army, the police also permanently stationed a company of the Brimob (Mobile Brigade) in Poso. A Brimob company headquarters and barracks now sit proudly on the hilltop opposite Pertamina Marketing Unit VII's Poso Depot in Moengko Baru (Poso Kota sub-district). Another Brimob company is to be posted in Korompeli Village (Lembo sub-district, Morowali district). The headquarters for this Company IV is currently being built.

Following the partitioning of Morowali district and Tojo Una-Una district 
from Poso district, Polri also partitioned its police sub-regions (Kepolisian resort, Polres). In Morowali, the establishment of the Polres followed the bloody attack on Beteleme Village, on 10 October 2003. At that time, national police chief General Da'i Bachtiar declared that a preliminary Polres would be immediately established in the district (Tempo Interaktif 10-10-2003; Sinar Harapan 11-10-2003). This plan was promptly realized, when Central Sulawesi regional police chief Brigadier General Drs H. Taufik Ridha inaugurated the Morowali Polres Office and swore in police Commissioner Drs Hanny Sulistyo Arianto as its first Kapolres (sub-region police chief) on 6 December 2003 in Morowali. In Tojo Una-Una, Polri established a separate Polres on 3 March 2005.

On the TNI-AD side, also following the partitioning of Morowali district from Poso district, the establishment of a new Military district Command (Kodim) there was just a matter of time. As a preliminary step, the deputy commander of Kodim 1307 Poso is no longer stationed in Poso, but rather in Kolonodale, Morowali district. The Morowali district government, in its 2003 Regional Budget, spent Rp 57 million to acquire land for the Morowali Kodim and Polres headquarters.

Thus, the violence that has occurred in Poso has provided multiple benefits for the military. Like killing two (or three) birds with one stone, the mobilization of troops to 'restore' security in Poso has in fact served as the entry for posting of organic combat forces, upgrading the quality and quantity of the military presence, and eventually expanding the number of TNI territorial commands, or at least maintaining the existing territorial commands. For example, new Military District Commands are to be established in the two new regencies recently split off from Poso, Morowali and Tojo Una-Una districts. And if the plan is realized to establish a new province of East Sulawesi, partitioned from Central Sulawesi, the possibility will be open to establish a new Military Sub-Area Command (Korem) in this region, and the police will also establish a new regional police (Polda).

This snowball effect will then lead to the establishment of a new Military Area Command (Kodam), separate from Kodam Wirabuana, which has its headquarters in Makassar. The new Kodam would have four provinces under it: North Sulawesi, Gorontalo, Central Sulawesi, and East Sulawesi, and probably have its headquarters in Manado. Kodam Wirabuana, meanwhile, would cover the provinces of South Sulawesi, Southeast Sulawesi, and the new province of West Sulawesi. This would not be new, because from 1969 to 1985, Sulawesi had two Kodam: Kodam XIII Merdeka, with headquarters in Manado, and Kodam XIV Hasanuddin, with headquarters in Ujung Pandang (Makassar). Since 1985, following the liquidation of the territorial commands, Kodam XIII and Kodam XIV were merged into Kodam VII Wirabuana, with its headquarters in Makassar (Lowry 1996:52, 56). A 
similar scenario of partitioning of Kodam has occurred in Maluku with the continuing violence there. Before the 1985 liquidation, there was a Kodam XV Pattimura with headquarters in Ambon; now, Kodam Pattimura has been revived, separate from Kodam Cenderawasih, which has its headquarters in Jayapura (see also George Junus Aditjondro 2001:114-5).

\section{Appointments and promotions}

There is a sort of general pattern that appointments and promotions are enjoyed by those security officials who had authority for security while violence was taking place. This can be seen from the appointments and promotions of numerous high and middle-ranking officers, both within Kodam VII Wirabuana (Military Area Command) and within the Central Sulawesi regional police. This creates the impression that Poso is considered a 'Spartan training' arena to prepare officers for appointments and promotions.

Several commanders of the Wirabuana Kodam later occupied prestigious positions. Among them are Maj. Gen. Suaidi Marasabesi, promoted to TNI Chief of General Staff; Maj. Gen. Slamet Kirbiantoro and Maj. Gen. Ahmad Yahya, who both later became commander of the Greater Jakarta Military Area Command. A former commander of the Operasi Cinta Damai Task Force later became Military Sub-Area Commander (Danrem) 132/Tadulako. And two former Military District Commanders (Dandim) enjoyed promotions to Chief of Staff of Military Sub-Area Command (Korem) 132/Tadulako. Within Polri, appointments and promotions were also enjoyed by several officers. Police Brigadier General Zainal Abidin Ishak and police Brigadier General Taufik Ridha both enjoyed promotions to regional police chief after serving as deputy chief of the Central Sulawesi regional police. Police commissioner Ricky Wakano, Head of the Criminal Investigation Section of the Central Sulawesi regional police was promoted to deputy chief of the Central Jakarta police sub-region, after he succeeded in arresting Pastor Damanik as a suspect in a firearms possession case. After serving as chief of the Poso police sub-region during a time full of violence, Deputy Chief Police Commissioner Djasman Baso Opu was appointed as sub-region police chief in Palu. Finally, Deputy Chief Police Commissioner Abdi Dharma Sitepu was promoted to sub-region chief of police of Poso after serving as acting commander of the Central Sulawesi Brimob unit.

These appointments and promotions indicate that the violence in Poso is not seen as a failure on the part of the security officers; they are absolved of any responsibility for the violence that takes place. In reality, violence certainly is an indicator of failure to maintain security and order in a region. Thus, the violence in Poso has directly benefited, rather than harming, these security officers in their appointments and promotions. 


\section{The businesses of the security forces}

The presence of combat troops and the expansion of the territorial commands cannot be seen simply as a response to the existence of horizontal violence. It is also very important to note the security forces' business interests - institutional, non-institutional, and criminal. In the case of TNI, one prominent institutional business since the violence first broke out in Poso is the fuel distribution business. The depot of Pertamina's Marketing Unit VII in Poso uses tank trunks owned by the Primkopad (Primer Koperasi Angkatan Darat, Army Primary Cooperative) of Korem 132 Tadulako. But the Primkopad is actually only a 'nameplate' to protect the fuel distribution operations from the Pertamina Depot done by two private companies: PT Kaliwangi and CV Arba Putra (Aditjondro 2004b:146). But the most significant form of business since the start of the Poso violence has been economic crimes, or what Aditjondro refers to as 'grey businesses'. These take the form of extortion by 'certain individuals' in uniform, protection for veiled prostitution operations, cockfighting, security guard businesses, hunting and smuggling of rare plant and animal species, trade in forest products, transportation of goods and passengers using official vehicles, security escort businesses, levies at guard posts, protection for property of certain businessmen or high officials, protection for the operations of businesses with large capital investment, and the illegal trade in firearms and ammunition (Aditjondro 2004b:149-50).

One form of economic crime correlated directly with the violence is, of course, the sale of bullets of various calibres. Members of the security forces on duty in the field regularly sell bullets to citizens. Several sources have stated that $5.56 \mathrm{~mm}$ calibre bullets are the ones most often sold. This type of bullet, which is typically used in long-bore weapons of the SS-1, AK-47, and M-16 types, is sold by military personnel in the field for between Rp 2,500 and $\operatorname{Rp~5,000~apiece.~However,~the~quantities~sold~are~usually~quite~small,~}$ only one to five bullets at a time.

Another significant form of economic crime is security services: providing security escorts for residents who need to travel around or across Poso when the violence is intense. The fees for this vary, depending on the distance of the journey and the current level of tension. The greater the distance or the more severe the violence, the higher the costs. PT Fajar Bahari, a company operating a road construction project in Bungku Selatan, Morowali district had to spend $\mathrm{Rp} 10$ million for escort services for a single journey in 2001. The money was paid to an officer in Korem 132/Tadulako. In return, around 20 TNI personnel and a military truck escorted the convoy of company vehicles carrying material and an excavator from Palu to Tompira village, Morowali district. A former employee of the company who led the convoy said that the soldiers involved told him they only received pocket money of $\operatorname{Rp} 150,000$ 
each. Fees for security escort services are not the monopoly of officers; lower ranking soldiers do it as well. If long distances are controlled by the commanders, shorter distances are controlled by regular soldiers. Residents in the villages in Lage, Pamona Utara, and Poso Kota sub-districts regularly pay fees to soldiers from Company B, Battalion 711/Raksatama, Kawua to escort them by motorcycle into the City of Poso when the tension level is high. For example, a number of candidate civil servants had to do this when they were in their pre-appointment period in the City of Poso in early July 2004. They paid soldiers between Rp 15,000 and Rp 20,000 for security services, following the shooting of a motorcycle taxi driver.

Another dominant pattern is the timber business. As the region is rich in forest products, soldiers on duty in Poso always see the timber business as a way to earn easy money. From the first Poso conflict (December 1998) to the third (May-June 2000), TNI personnel from Kostrad battalions 721, 722, 723, 724, 725 and 726 from South Sulawesi, together with personnel from Company C, Infantry Battalion 711/Raksatama, Poso, were heavily involved in collection of and trade in ebony. In March 2003, the Poso district Forestry and Plantations Service foiled a shipment of 70 cubic meters of undocumented plywood in Pendolo, Pamona Selatan. According to the Head of the Poso Forestry and Plantations Service, the wood belonged to certain TNI personnel in South Sulawesi (George Junus Aditjondro 2004b:153). Around a month later, the Poso Forestry and Plantations Service foiled another shipment of 6 cubic meters of illegal wood owned by a member of Kodim 1307 Poso. It was reported that the logs were being transported using military trucks. TNI personnel even own illegal sawmills (Poso Post 27-4-2003, 10-5-2003).

Polri personnel also see the wood business as a source of illicit funds. An informant in the wood business in Poso said that their businesses are often the object of extortion from the security forces, including the police. A number of sawmill operators say they have been extorted by local police personnel. They state that the extortion took place at the Poso police sub-region headquarters and involved the top officers in the local police sub-region. The method used was that, under the guise of Operasi Sintuwu Maroso, officials would stop trucks carrying wood to the sawmills. Even though the vehicles and the logs all had proper documents issued by the Poso Forestry Service, they were still taken to the police headquarters. There they were forced to part with a certain amount of money if they wanted the trucks and logs to be released. Businessman Hengky Tungkanan experienced this; he had to hand over Rp 70 million as a down payment on a total of Rp 100 million to the head of the Poso police sub-region's Criminal Investigations Unit which was witnessed by the deputy police chief. The deputy chief then took the money to the sub-region police chief. Other victims included Toni Hantowo, who paid Rp 25 million, Chi Dewi (Rp 125 million), Hermawan (Rp 25 million), 
and La'ba (Rp 25 million) (Nuansa Pos 26-7-2004, 2-8-2004).

In July 2004, a policeman from Palu who was posted to Poso was involved in transporting undocumented logs owned by a sawmill operator in Mapane village, Poso Pesisir. The five truckloads of logs were transported toward Palu under the policeman's escort. A primary source who was on the journey said that the sawmill owner paid the policeman Rp 5,000,000 for this work. The policeman was also provided with additional money to pay off Polri and TNI personnel at each guard post along the Trans Sulawesi Highway in Poso Pesisir sub-district. He said that the policeman made payments ranging from Rp 50,000 to Rp 300,000 at each post. ${ }^{11}$

In Morowali district, the involvement of the security forces in the wood business is also quite blatant. In December 2003, the local police seized 60 cubic meters of wood that was being transported to Makassar on four trucks, escorted by two soldiers from Company B, Infantry Battalion 714/Sintuwu Maroso. The wood, from Bungku, allegedly belonged to Made Kuswandi, and there were rumours that he had the backing of an army officer in Makassar. ${ }^{12}$

Economic crimes involving the security forces in the violence in Poso have also occurred in the form of robberies and loss of property. During July 2000, many such cases befell residents in Poso. For example, on 11 July 2000, TNI$\mathrm{AD}$ personnel who were searching for sharp weapons in Uelene village took Rp 4,500,000 from Anwar Mbalowo. Earlier, on 8 July 2000, for no apparent reason, TNI-AD personnel took Rp 2,000,000 from Santo Lagi in Beteleme village, Morowali district. And a computer, a voltage stabilizer, an SSB radio, and an alarm disappeared without a trace from the Pendolo Bank Rakyat Indonesia Unit in Pamona Selatan sub-district when TNI-AD personnel were guarding the BRI building on 9 July $2000 .^{13}$

Other serious economic crimes have emerged in cases of diversion of humanitarian aid funds for Poso. The cabals to carry out this misappropriation of humanitarian aid funds have blatantly included the security forces. Anwar M. Ali, Head of the Poso District Social Welfare Service, who was caught up in the aid misappropriation case, alleged that he had given some of the Poso humanitarian aid funds to local security officials. He confirmed that he had given Rp 112 million to Colonel Joko Purwoko, coordinator of the National Intelligence Agency (BIN) Central Sulawesi Region, and Rp 50 million to Deputy Police Chief Abdi Dharma Sitepu, chief of the Poso subregion police (Seputar Rakyat, Edition 03/Year II/2004). 
In the long term, the presence of combat troops and the expansion of the territorial commands is actually an investment to guard the natural wealth in the eastern part of Central Sulawesi. This presence is needed to provide protection for the penetration of large-scale capital into the area. It is intended to overcome public opposition when their agricultural land is expropriated or disturbed by the presence of extractive industries in the mining, forestry, or large-scale plantation sectors. It is known that many giant companies, both national and trans-national, are either getting ready to or are already extracting natural wealth from the area. Among these is the world's second largest nickel mining company, Canada-based PT Inco, which is preparing to exploit nickel matte in the Bungku area of Morowali district (Arianto Sangaji 2002). There is also a plan to exploit natural gas in Toili and Batui, Banggai district and in Tiaka, Teluk Tomori, Morowali district.

\section{Elections for president and heads of regions}

The protracted violence in Poso has provided political advantages to former and active members of the military elite in their competition for political positions. This is clearly seen in the presidential election results in Poso, Morowali, and Tojo Una-una. In the first round of the presidential election in July 2004, two presidential candidates with military backgrounds - Susilo Bambang Yudhoyono and Wiranto - took first and second places in Poso, Morowali, and Tojo Una-una. The same thing happened again in the second round in September 2004, when the ticket of Susilo Bambang Yudhoyono and Jusuf Kalla won. There was a sort of nostalgia among voters to vote for these two candidates, based on a feeling that a president with a military background would better guarantee a sense of security.

This tendency to elect government leaders with security force backgrounds was also evident in the election for district head of Poso in mid 2005. The field of candidates for district head of Poso to succeed Muin Pusadan was full of candidates with 'green' and 'brown' backgrounds. One name often mentioned was police Lt. Col. (retired) Luther Manganti, former chief of the Toli-Toli police from 1993 to 1997 and former member of the Central Sulawesi DRPD (provincial assembly) for the 1999-2004 period. Another name was Lt. Col. Dede K Atmawijaya, formerly commander of Kodim 1307 Poso and Chief of Staff of Korem 132 Tadulako. Others included police Lt. Col. (retired) Piet Inkiriwang, and Lt. Col. (retired) Rudolf Rukka, former district head of Central Maluku, rumoured to be nominated by the Pancasila Patriot Party. 


\section{Conclusion}

Reformasi, as an entry point to place the security forces under the control of the civilian government, has not gone smoothly. The rapid transition has been coloured by a tense relationship between the civilian government and the security forces, both because the institutions are not properly prepared and because of the tug-of-war between the interests of the political elite and those of the security force elite. One disappointing result of Reformasi is the government's failure to create a sense of security among the populace. Indonesia's security forces, which during the New Order era were so solid and strong, seem to have lost the power to create social order in line with their legitimate duties and functions. Regional violence, such as that in Poso, is one indication of this.

Violence under the pretext of ethnic and religious conflict has actually created an opportunity for the security forces to restore their image and privileges, which had declined sharply since the start of Reformasi in 1998. First, the violence in Poso has given rise to a significant security force presence in the area. The deployment and addition of organic troops, and the expansion of territorial commands or of other security institutions on the same level, all prove that the security forces have succeeded in forcing the civilian government to bow to their institutional interests. This means that the violence in Poso has had a beneficial political impact for the security forces. Second, members of the security forces have benefited not only institutionally but also personally from the protracted violence in Poso - in terms of career advancement, access to economic activity, and political positions in government. 